\title{
Ekaristi: Akar Segala Kekudusan menurut R. Cantalamessa dan Benediktus XVI
}

\author{
Veronika Puji Astuty a,1 \\ Novisiat Konggregasi SPM, Malang a \\ gabriella.spm@gmail.com ${ }^{1}$
}

\section{Keywords:}

Raniero Cantalamessa; Benediktus XVI;

Ekaristi; pengudusan; antroposentrisme; transformasi

\begin{abstract}
The Church as the mystical body of Christ is called to sanctification (LG 42). The Church's challenge to live up to the vocation of sanctification faces the challenge of antrophocentrism in modern times. The severity of the challenges experienced by the Church in modern times demands militancy of the spiritual life that is rooted in the Eucharist. This article aims to discuss the Eucharist as the root of all forms of the Church sanctification in the world as viewed by Raniero Cantalamessa and Pope Benedict XVI. Both Cantalmessa and Pope Benedict XVI show that the sanctification within the Church is rooted in the Eucharist. Through Eucharist as the real encounter, the Church is transformed by the divine power of Christ which revives, moves, supports, and strengthens the pilgrimage of Church in this world. This problem is approached by scrutinizing the viewpoints by Raniero Cantalamessa and Pope Benedict XVI by carrying out the critical history method and library research. Then, the writer synthesizes the two viewpoints on the Eucharist as the root of sanctification. This writing is expected to be a viewpoint contribution to spiritual life of all Christians in living the call to the sanctification.
\end{abstract}

\section{PENDAHULUAN}

Panggilan kekudusan merupakan bentuk partisipasi Gereja terhadap karya pendamaian Allah yang terpenuhi dalam diri Yesus Kristus melalui sengsara, wafat dan kebangkitan-Nya. Kesinambungan partisipasi Gereja dari zaman ke zaman melalui panggilan kekudusan terletak pada kesatuan-Nya dengan Kristus. Ekaristi adalah saat Kristus hadir secara nyata dan bersatu dengan Gereja. Persatuan Gereja dengan Kristus di dalam Ekaristi memungkinkan terjadinya transformasi sifat, nilai dan ajaran Kristus. Pokok permasalahanya adalah dalam era globalisasi ini sejauh mana Ekaristi berdampak dan dan berdaya ubah dalan diri Gereja? Jika Ekaristi berdampak dan berdaya ubah dalam diri Gereja sebagai Tubuh Mistik Kristus seberapa efektif ber- 
dampak dalam kehidupan sosial masyarakat yang semakin sekular? Pokok permasalahan ini yang akan penulis olah dalam tulisan ilmiah ini dengan memakai metode pustaka deskriptif-analitik dengan bentuk komparasi antara dua pemikiran tokoh yakni Raniero Cantalamessa dan Paus Benediktus XVI. Pemikiran teologis kedua tokoh tersebut dibandingkan dengan metode historis kritis. Tulisan ini disusun berdasarkan perspektif teologis, khususnya Sakramentologi sebagai batasan dan jangkauan dengan berfokus pada pandangan kedua tokoh.

\section{PANGGILAN KEKUDUSAN BAGI UMAT KATOLIK DI ERA MODERNISASI}

Panggilan kepada kekudusan bagi umat kristiani di zaman modern tidak mudah. Kemajuan teknologi dan media komunikasi di era modern menurut penulis lambat laun menjauhkan Gereja dari intimitas dengan Allah. Rasa perasaan (sense) akan kehadiran Yang Ilahi dalam diri sesama, alam ciptaan dan dalam diri sendiri semakin retak. Retaknya hubungan manusia dengan Yang Ilahi berdampak pada partisipasinya menguduskan dunia.

Paus Fransiskus menggemakan kembali kesadaran Gereja akan panggilan kepada kekudusan. Melalui seruan apostolik ketiga yang berjudul Gaudete et Exsultate (selanjutnya disingkat G.Ex), Paus Fransiskus memberikan pandangan yang luas akan makna kekudusan sebagai panggilan dasar umat kristiani. Fr. Frank Donio, seorang direktur Catholic Apostolate Center berpendapat bahwa seruan pastoral Paus Fransiskus tentang kekudusan bukanlah hal yang mudah diterima oleh sebagian besar umat kristiani sebagai konsekwensi sakramen baptis. ${ }^{1}$ Panggilan kekudusan berlaku untuk semua umat kristiani yang dibaptis dan bukan hanya melalui panggilan hidup bhakti.

Paus Fransiskus mendefinisikan 'kekudusan' dengan mengacu pada definisi Paus Emeritus Benediktus XVI yakni "kekudusan adalah kasih yang dihidupi dalam kepenuhan". ${ }^{2}$ Ia memberikan penjelasan lebih lanjut dengan mengutip ajaran pendahulunya yakni bahwa kasih yang dihidupi dalam kepenuhan orang-orang yang dibaptis berasal dari kasih Kristus yang hidup dalam diri umatNya berkat daya Roh Kudus. Hal ini menjadi tolak ukur kekudusan dalam diri umat kristiani (G.Ex 21). ${ }^{3}$ Jalan menuju kekudusan yang dianjurkan oleh Paus Fransiskus adalah sering merayakan Sakramen Ekaristi. ${ }^{4}$ Seperti diajarkan oleh Paus Emeritus Benediktus XVI, Ekaristi sangatlah penting untuk dapat menjalankan misi panggilan kekudusan sebab dalam Ekaristi umat kristiani disatukan menjadi satu daging dan dalam komuni suci umat kristiani menjadi satu Roh dengan Kristus. ${ }^{5}$

Ajaran Gereja mengajarkan bahwa panggilan kepada kekudusan, bukanlah sesuatu yang ditambahkan, sebab Umat Allah merupakan anggota Tubuh Mistik Kristus. Kristus telah menyerahkan diri-Nya untuk menguduskan Gereja (LG 39). Umat Allah dalam segala kondisi hidup, tugas serta keadaan dipanggil kepada jalan kekudusan.

\footnotetext{
1 Frank Donio, "Gaudate et Exsultate: The Call to Holiness in Today's World", April 2018, tersedia dari https://www.catholicapostolatecenter.org/blog/gaudete-et-exsultate-the-call-toholiness-in-todays-world; diakses 10 Mei 2018.

2 Fransiskus, Gaudete et exultate (19 Maret 2018), art 21 (Padraig McCormack, Ireland: Veritas Puplications, 2018). "Holiness is charity lived to the full."

3 "As a result, the measure of our holiness stems from the stature that Christ achieves in us, to the extent that, by the power of Holy Spirit, we model our whole life on his."

4 Alan L. Anderson, "A Curious Absence in Gaudate et Exultate", April 2018; Tersedia dari https://www.thecatholicthing. org/2018/04/15/a-curious-absence-in-gaudete-et-exsultate/; diakses 11 Mei 2018.

5 Alan L. Anderson, "A Curious Absence in Gaudate et Exultate".
} 
Atas dasar iman, umat kristiani menerima rahmat dari Bapa untuk bekerja sama dengan kehendak Ilahi-Nya yang menampakkan dan menghadirkan cinta kasih Allah terhadap dunia (LG 41). Manusia hanya dapat menghadirkan cinta kasih Allah jika dalam dirinya dipenuhi olehnya. Cinta kasih Allah bertumbuh dan berakar dalam jiwa manusia diantaranya melalui penerimaan sakramen-sakramen terutama Ekaristi (LG 42).

Berpijak pada ajaran Gereja dan anjuran Bapa Suci akan mendasarnya panggilan kepada kekudusan, sangat penting bagi umat kristiani untuk kembali ke kedalaman hidup rohani untuk bersatu dengan Allah Sang sumber kekudusan. Persatuan dengan Kristus dalam sakramen Ekaristi menjadi akar yang menopang panggilan Umat Allah kepada kekudusan. Sebab Ekaristi sebagai sumber dan puncak hidup Gereja (LG 11) memberikan daya yang mengubah.

Gereja sebagai Umat Allah yang hidup di zaman modern ini perlu menggali makna kekayaan Ekaristi secara kontekstual. Ekaristi bukan sekedar sebuah ritus yang dirayakan. Hal yang mendasar dalam Ekaristi adalah hidup dalam kesatuan ilahi dan insani. Menurut beberapa sejarawan, Gereja mampu bertahan dari komunitas awali hingga saat ini karena pengalaman eskatologis koinonia dalam Ekaristi baik secara vertikal dengan kepalanya maupun horizontal yakni dengan sesama. ${ }^{6}$

Bertolak dari fenomena dampak modernisasi bagi keberlangsungan hidup, peran Gereja di tengah dunia sangatlah penting. Panggilan kepada kekudusan bagi setiap pribadi umat Allah menjadi harapan bagi dunia yang sedang mengerang kesakitan bagai

6 S.T Kimbrough Jr, Holiness in The Perspective of Eucharistic Theology (Orthodox and Wesleyan Spirituality, SVS Press, 2002), 101-116. wanita yang melahirkan. Panggilan Gereja kepada kekudusan memberikan wajah baru bagi dunia yang suram. Melalui panggilan kekudusan, Gereja diundang untuk memberikan oase, menghadirkan pandangan yang berbeda dari pandangan umum yang berkembang. Untuk itu Gereja perlu kembali kepada sumber dan puncak hidupnya yakni Ekaristi. Daripadanya Gereja menyerap secara penuh daya-daya kekudusan dari Kristus. Dalam Ekaristi umat kristiani mengalami kesatuan dengan Kristus secara nyata dan menerima motivasi serta kekuatan sebagai seorang Kristen sejati. Oleh Tubuh dan Darah Anak Domba yang telah dikorbankan setiap kali Ekaristi, Kristus memelihara dan memberi kekuatan kepada Gereja untuk mengikuti jejak-Nya (bdk. 1 Ptr 2:21). ${ }^{7}$ Untuk menggali lebih dalam akan esensi Ekaristi sebagai akar dari segala bentuk kekudusan berikut akan diuraikan gagasan dua tokoh yang saling melengkapi dan memperkuat.

\section{RANIERO CANTALAMESSA: KRISTUS PANCARAN DAN SUMBER KEKUDUSAN GEREJA}

Raniero Cantalamessa, seorang pengkhotbah kepausan mempunyai pemikiran tentang Ekaristi sebagai pengudusan Gereja. Berangkat dari pemahamannya tentang Kristus yang mempunyai dua elemen kekudusan yakni tidak mempunyai dosa dan ketaatan kepada kehendak Bapa-Nya, ${ }^{8}$ Cantalamessa berpendapat bahwa di dalam diri Kristus terpantul kekudusan Allah. Kristus satu-satunya manusia yang kudus, "Maha Kudus” yang sejati. Karena kekudusan-Nya

7 John Paul II, General Audience 8 April 1992, tersedia dari https://adoremus.org/2007/12/31/Catechesis-of-His-Holiness-John-Paul-II-on-the-Eucharist/; diakses 11 Mei 2018.

8 Raniero Cantalamessa, Jesus Christ, The Holy One of Cod, diterjemahkan oleh Alan Neame (Collegevile: Liturgical Press, 1991), 13. 
Kristus menjadi pusat dari realitas dan sejarah (bdk. Dan 9:24). ${ }^{9}$ Kristus adalah sumber dan puncak kekudusan.

Menurut Cantalamessa, kekudusan dapat dicapai dengan dua cara yakni melalui iman dan sakramen-sakramen. Iman adalah satu-satunya kemungkinan yang menghubungkan manusia dengan Kristus. Cantalamessa mengutip ajaran St. Agustinus "Siapa yang percaya kepada Kristus menyentuh Kristus". ${ }^{10}$ Dengan iman manusia dapat berelasi dengan Allah sumber kekudusan. Dengan iman Kristus memberikan hatinya bagi seluruh umat manusia (bdk. Ef 3:17). Namun iman dapat disentuh langsung dan bekerja secara efektif dalam sakramen. ${ }^{11}$

Kristus mengalirkan kekudusan melalui sakramen baptis dan Ekaristi. Sakramen baptis menjadi gerbang Gereja untuk masuk dalam himpunan Anak-anak Allah. Sakramen Ekaristi menjadi akar yang daripadanya Gereja mendapatkan daya-daya Ilahi dan warisan pemberian diri Kristus kepada kehendak Bapa. Melalui kedua sakramen tersebut Gereja lestari memelihara panggilan kekudusannya oleh karena daya transformasi sakramen.

\section{Transformasi Kekudusan melalui Sakramen}

Kristus suci dan membuat yang dibaptis juga suci. Kristus sebagai Putera Allah menjadikan yang dibaptis juga sebagai anak-anak Bapa serta ahli waris (Rm 8:17). ${ }^{12}$ Baptisan mempunyai dampak yang istimewa dalam hidup orang Kristiani. Sebab dengan baptisan orang masuk dalam himpunan para pilihan, menjadi milik Kristus lebih dari dirinya sendiri, begitu pula Kristus menjalin keintiman dan bersatu dengan umat pilihan-Nya

\footnotetext{
9 Raniero Cantalamessa, Jesus Christ, The Holy One of God, 14

10 Raniero Cantalamessa, Jesus Christ, The Holy One of God, 20.

11 Raniero Cantalamessa, Jesus Christ, The Holy One of God, 20.

12 Raniero Cantalamessa, Jesus Christ, The Holy One of God, 19.
}

(1 Kor 6:19-20). ${ }^{13}$ St. Paulus dalam suratnya kepada jemaat di Filipi memberikan kesaksian bahwa ukuran kebenaran bukan karena mentaati hukum Taurat melainkan kepercayaan akan Kristus. Kekudusan yang ada dalam dirinya bukanlah miliknya melainkan milik Kristus (Fil 3:9). ${ }^{14}$ Kristus menganugerahkan rahmat kekudusan dalam diri setiap orang yang dibaptis. Sakramen baptis mengembalikan rahmat pengudusan yang semula hilang karena dosa.

Melalui sakramen Ekaristi manusia secara langsung dapat berkomunikasi dengan Allah melalui Kristus dan Kristus mentransformasikan diri-Nya ke dalam diri umat Kristiani. ${ }^{15}$ Setiap kali Ekaristi dirayakan, Gereja senantiasa diperbarui. Ekaristi tidak hanya mempersatukan Gereja sebagai communio, melainkan Kristus mempersatukan seluruh Gereja dengan diri-Nya. Dalam satu communio Gereja bukan terdiri dari dua tubuh, dua pikiran, dua kehendak melainkan satu tubuh, satu pikiran dan satu kehendak dengan Kristus (bdk. 1Kor 6:17). ${ }^{16}$ Maka kekudusan yang senantiasa diperbarui setiap kali Gereja merayakan Ekaristi menggerakkannya untuk keluar dari dirinya sendiri. Kekudusan berkat persatuan dengan Kristus dalam Ekaristi mengandung perutusan untuk menguduskan dunia, yakni dengan pelayanan kepada sesama.

Di dalam Ekaristi tubuh dan darah Tuhan memberikan kepada Gereja energi Ilahi. ${ }^{17}$ Penyerahan diri-Nya di kayu salib melampaui batas waktu dan ruang. Ia mencintai Gereja sejak Allah menciptakannya

\footnotetext{
13 Raniero Cantalamessa, Jesus Christ, The Holy One of God, 19.

14 Raniero Cantalamessa, Jesus Christ, The Holy One of God, 19.

15 Raniero Cantalamessa, Jesus Christ, The Holy One of God, 21.

16 Raniero Cantalamessa, This is My Body: Eucharistic Reflections Inspired by Adoro Te Devote and Ave Verum (Boston: Pauline Books and Media, 2005), 98.

17 Raniero Cantalamessa, The Mystery of the Transfiguration (Cincinnati, Ohio: St. Anthony Messenger Press, 2008), 84.
} 
hingga akhir zaman. ${ }^{18}$ Cantalamessa mengutip pemikiran Gabriel Marcel dalam bukunya Loving the Church: Scriptual Meditations for the Papal Household bahwa mahluk itu ada karena telah dicintai. Ini terutama berlaku untuk Gereja. ${ }^{19}$ Ia menjadikan Gereja "suatu kurban hidup yang berkenan kepada Allah". ${ }^{20}$ Dengan demikian pengudusan Gereja tidak hanya dimungkinkan pada saat Ekaristi menjadi lambang hingga peristiwa. Pengudusan Gereja berlangsung terus menerus hingga Kristus datang untuk kedua kalinya. Gereja senantiasa dalam lingkup persatuan antara Allah dan manusia berkat Ekaristi, berkat Roh Kudus yang dikaruniakan Kristus kepada Gereja-Nya. Kristus berada dalam Gereja, karena RohNya memberi kehidupan pada Gereja. Dan Gereja diutus Kristus untuk menjadi sakramen keselamatan-Nya di dunia. Dari dalam diri Kristus Gereja senantiasa mendapatkan energi dan nutrisi Ilahi.

\section{Ekaristi sebagai Pusat Hidup Gereja dan Dunia}

"Dari Ekaristi Gereja mendapatkan hidupnya. Dari roti kehidupan Gereja diberi makan oleh-Nya" (EE art. 7). Ajaran Paus Yohanes Paulus II akan keagungan dan daya Ekaristi bagi kehidupan Gereja ini nyata adanya. Dalam pandangan Cantalamessa, Ekaristi digambarkan bukan hanya pusat bagi Gereja namun dunia. Ekaristi berada di pusat tiga lingkaran yang konsentris: lingkaran pertama menggambarkan alam semesta, lingkaran kedua Gereja dan lingkaran paling dalam adalah Ekaristi atau Hostia. Hostia menjadi pusat seluruh umat manusia dan

18 Raniero Cantalamessa, Loving the Church: Scriptual Meditations for the Papal Household (U.S.A.: St. Anthony Messenger Press, 2005), 44.

19 Raniero Cantalamessa, Loving the Church: Scriptual Meditations for the Papal Household, 45.

20 Raniero Cantalamessa, The Eucharist Our Sanctification, translated by Frances LonerganVilla (Collegeville, Minnesota: The Liturgical Press, 1993), 15. alam semesta yang tidak bernyawa. Cantalamessa menjelaskannya demikian: "Ekaristi tampak sebagai pusat dan matahari, bukan hanya bagi Gereja, tetapi bagi seluruh kemanusiaan dan seluruh alam semesta yang tak berjiwa." ${ }^{21}$ Gereja menyadari Kristus sebagai pusat, maka daya pengudusan Kristus bagi dunia semestinya mengalir secara efektif dalam hidup dan gerak Gereja.

Ekaristi bagi Gereja bersifat dinamis dan aktif, dari dalamnya Gereja dibentuk. Yesus Kristus yang senantiasa bersatu menjadi satu tubuh dengan Gereja melalui Roh-Nya (Ef 4:4). Hubungan Gereja dengan Yesus Kristus ini menurut Cantalamessa merupakan "misteri besar" dan menjadi tanda sakramentalnya. ${ }^{22}$ Yesus Kristus yang senantiasa hadir menyertai Gereja dalam Ekaristi membangun Gereja dari dalam dan membuat Gereja berkembang secara kualitatif, karena Ekaristi selalu mengubah Gereja untuk semakin serupa dengan Kristus Kepala Tubuh. ${ }^{23}$ Ekaristi menjadi ragi Gereja, maka kehadirannya di tengah dunia bagaikan makanan, suatu bagian yang terpenting bagi kelangsungan hidup. Kristuslah muara Gereja, Ia membentuk Gereja melalui empat tahap yakni konsekrasi, komuni, kontemplasi dan teladan. ${ }^{24}$

\section{Proses Pembentukan Gereja dalam Ekaristi}

Kristus membentuk Gereja melalui konsekrasi. Untuk dapat memahami Ekaristi membentuk Gereja melalui konsekrasi perlu dipahami terlebih dahulu mengenai konsekrasi menurut teologi dan liturgi Ekaristi Barat. Teologi dan liturgi Ekaristi Barat memahami konsekrasi roti dan anggur da-

\footnotetext{
21 Cantalamessa, The Eucharist Our Sanctification, 16.

22 Cantalamessa, Loving the Church: Scriptual Meditations for the Papal Household, 43.

23 Cantalamessa, The Eucharist Our Sanctification, 16.

24 Cantalamessa, The Eucharist Our Sanctification, 17.
} 
lam keseluruhan Doa Syukur Agung. ${ }^{25}$ Doa Syukur Agung disampaikan oleh Gereja bersama Kristus kepada Bapa dalam Roh Kudus. ${ }^{26}$ Kehadiran pribadi Kristus dan penebusan-Nya dalam kurban salib mengalami penampakan objektif dalam keadaan real atau transsubstantiatio Tubuh dan DarahNya dalam rupa roti dan anggur.

Cantalamessa dengan mengikuti pandangan St. Agustinus memandang konsekrasi dalam terang baru yakni "rahasia kita juga dirayakan di altar", artinya merayakan Ekaristi dengan benar berarti melakukan juga apa yang Tuhan lakukan. Konsekrasi bagi Gereja sebagai Tubuh Mistik Kristus (bdk. 1Kor 12:12) berarti turut ambil bagian dengan tindakan Kristus yakni menyerahkan diri secara penuh kepada kehendak Bapa. Hal mendasar dalam ambil bagian Gereja dalam konsekrasi adalah kerelaan untuk mempersembahkan dirinya bersama Kristus. Cantalamessa menegaskannya demikian, "Biarkanlah Aku mempersembahkan kepada Bapa Tubuh-Ku sendiri, yang adalah kamu: jangan menghalangi Aku mempersembahkan Diri-Ku kepada Bapa secara sempurna, selama ada satu anggota Tubuh-Ku yang menolak mempersembahkan dirinya bersamaku." 27

Kata-kata institusi "Ambilah dan makanlah; inilah Tubuh-Ku yang diserahkan bagimu" (bdk. Mat 26:26; Luk 22:9) menurut Cantalamessa merupakan pengungkapan seluruh diri Yesus yang telah wafat, bangkit dan hidup selamanya (bdk. Why 1:8). ${ }^{28}$ Kristus seutuhnya, kepala dan tubuh yang tidak terpisahkan. Dengan demikian kata-kata in-

25 E. Martasudjita, Ekaristi, Tinjauan Teologis, Liturgis, dan Pastoral (Yogyakarta: Kanisius, 2005), 356.

26 Martasudjita, Ekaristi, Tinjauan Teologis, Liturgis, dan Pastoral, 151.

27 Cantalamessa, The Eucharist Our Sanctification, 17.

28 Cantalamessa, The Eucharist Our Sanctification, 19. stitusi ini tidak hanya merupakan penyerahan diri Yesus melainkan juga Gereja-Nya. Kesatuan dengan Yesus tidak membedakan perbedaan konsekwensi sebagai satu tubuh. Bagi Cantalamessa makna penyerahan diri Gereja bersama Kristus merupakan suatu rahasia yang mengagumkan. Yesus telah mempersatukan Gereja kepada diri-Nya dalam perbuatan yang teragung dan terkudus dalam sejarah; dalam perbuatan satu-satunya yang hanya pantas bagi Allah, pantas bagi kekudusan dan kemahakuasaan-Nya. ${ }^{29}$

Kristus menguduskan Gereja melalui konsekrasi. Terdapat dua Tubuh di atas altar pada saat konsekrasi yakni Tubuh nyata Kristus dan tubuh Gereja yang hadir secara mistik karena hubungan yang tidak terpisahkan dengan Sang Kepala Tubuh. Menurut Cantalamessa dengan dua persembahan kurban di atas altar maka terdapat dua eplikese. Eplikese pertama ialah permohonan kepada Roh Kudus untuk mengubah roti dan anggur menjadi Tubuh dan Darah Kristus. Seruan yang pertama: "Maka dengan bersembah sujud kami mohon ya Tuhan, kuduskanlah dengan kuasa Roh-Mu persembahan yang kami unjukkan ini, sehingga menjadi Tubuh dan Darah Putra-Mu, Tuhan kami Yesus Kristus.” Epiklese kedua ialah permohonan kepada Roh Kudus untuk memperkuat Gereja dengan Tubuh dan Darah Kristus sehingga sungguh dapat menjadi satu tubuh dan satu jiwa dengan Kepala Tubuh yakni Yesus Kristus. Epiklese kedua dengan rumusan berikut, "Semoga kami yang diperkuat dengan Tubuh dan Darah Putra-Mu dipenuhi dengan Roh Kudus-Nya sehingga menjadi satu tubuh dan satu jiwa dalam diri Kristus. Semoga oleh-Nya kami dijadikan suatu persembahan kepada-Mu untuk selama-lamanya."

29 Cantalamessa, The Eucharist Our Sanctification, 19. 
Gereja bersama dengan Kristus menjadi kurban yang hidup dan berkenan kepada Allah berkat karya Roh Kudus dalam konsekrasi. Gereja menjadi satu jiwa dengan Yesus Kristus sebagai Kepala Tubuh. Keserupaan dengan Kristus juga terintegrasi melalui komuni. Tubuh dan Darah Tuhan sebagai makanan menjadi keberlangsungan hidup. Kristus bukan hanya memberikan diri-Nya sebagai makanan namun Ia juga menjadi penjamin pemelihara hidup. Ia sebagai Roti Hidup yang turun dari surga untuk memberi hidup kepada mereka yang menerimanya serta mengubah mereka ke dalam diri-Nya. Gereja digerakkan oleh Kristus untuk hidup di dalam Dia.Kristus menjadikan kita serupa dengan-Nya dalam perasaan, keinginan dan pola pikir. Dengan kata lain Ia menciptakan dalam diri kita "perasaan-perasaan yang sama dalam Kristus Yesus"(bdk. Fil 2:5). Kesatuan relasi ini berdasarkan kesatuan relasi-Nya dengan Bapa seperti disabdakanNya "Sama seperti Bapa yang hidup mengutus Aku dan Aku hidup oleh Bapa, demikian juga barangsiapa yang memakan Aku, akan hidup oleh Aku" (Yoh 6:57). Cantalamessa menafsirkan sabda Yesus ini sebagai sumber dan tujuan Gereja yakni hidup oleh dan bagi Dia. ${ }^{30}$ Komuni semakin membuat Gereja tidak hidup bagi dirinya sendiri tetapi semakin membiarkan Kristus menguasai dirinya (bdk. Gal 2:20).

Komuni selain berdimensi vertikal, antara Gereja dan Allah Tritunggal juga mempunyai dimensi horisontal, yakni hubungan Gereja dengan sesama. Dimensi horisontal, yakni relasi Gereja dengan sesama bagi Cantalamessa merupakan buah yang tidak dapat dipisahkan dari persatuan dengan Allah Tritunggal. Perwujudan sebagai roti ekaristis bagi sesama tidaklah otomatis, diperlukan kerja sama antara rahmat Allah dan kehendak manusia. Kristus yang diterima dalam komuni adalah Kristus yang sama pula diterima oleh saudara yang lain sebagai anggota Gereja yang lain.

Dengan demikian dalam komuni Gereja sekaligus dipersatukan dengan Allah, dan persatuan dengan Allah tersebut menjadi landasan membangun persekutuan dengan saudara-saudari. Persatuan umat Allah menjadi lambang Kristus yang hadir di tengah dunia sepanjang segala zaman. Dalam persekutuan Gereja mengasihi Allah dengan segenap hati, jiwa dan dengan segenap akal budi, sekaligus Gereja mengasihi sesama manusia seperti diri sendiri (bdk. Mat 22:37-39)

\section{Integrasi Ekaristi dalam Hidup Gereja}

Jalan menuju kekudusan tidak lain adalah jalan menuju kesempurnaan hidup kristiani yakni semakin menyerupai Kristus secara total. Menurut Cantalamessa, jalan ini ditempuh dengan dua jalan. ${ }^{31}$ Pertama melalui sakramen-sakramen, terkhusus Sakramen Ekaristi yang bersifat objektif atau misteri. Kedua melalui kontemplasi yang bersifat subjektif atau mistik. Dua jalan ini tidak bisa dipisahkan satu dengan yang lain untuk menuju kekudusan.

Kontemplasi memungkinkan rahmat yang diterima dalam sakramen- sakramen membentuk kehidupan batiniah Gereja, yakni pikiran, cinta, kehendak dan ingatan. ${ }^{32}$ Menyerupai Kristus, tidak cukup hanya makan dan minum Tubuh dan Darah-Nya. Orang harus merenungkan dan mengenang misteri-Nya. Kontemplasi merupakan salah satu bentuk merenung yakni dengan mengikat diri secara intuitif pada kenyataan

31 Cantalamessa, The Eucharist Our Sanctification, 53.

32 Cantalamessa, The Eucharist Our Sanctification, 54. 
Ilahi, merasa gembira karena menemukan kebenaran. Kontemplasi kristiani tidak pernah satu jalur, selalu dua pandangan saling bertemu: pandangan manusia kepada Allah dan pandangan Allah kepada manusia. ${ }^{33}$ Sementara mengenang yang berarti mengingat (remember) berasal dari kata Latin "recordari". Secara etimologis berarti menaikkan lagi (re) ke permukaan hati (cor). Mengenangkan tidak hanya kegiatan akal budi melainkan kegiatan kehendak dan hati. Mengenang berarti berpikir dengan cinta. ${ }^{34}$ Dengan terus menerus mengenangkan Kristus dan cinta-Nya pikiran akan berakar dalam jiwa, selanjutnya akan mempengaruhi seluruh pola hidup manusia. Merenung dan mengenang dirangkai dalam satu kegiatan yakni kontemplasi.

Kontemplasi dalam hidup manusia berdampak semakin terbuka akan karya Allah dalam diri dan hidup, menaruh pikiran dan perasaan yang terdapat dalam Kristus Yesus (bdk. Fil 2:5), memikirkan yang Allah pikirkan bukan yang manusia pikirkan ( $b d k$. Mat 16:23). Prioritas terhadap kepentingan dan kemuliaan diri sendiri merupakan hambatan bagi orang untuk mengalami kesatuan dengan Kristus. Sebaliknya orang yang murni hatinya semakin melupakan kepentingannya sendiri dan mengutamakan kepentingan Allah. ${ }^{35}$

Ekaristi adalah satu misteri yang harus diteladani dan dihayati. ${ }^{36}$ Sifat kekudusan yang ada di dalam Gereja seluruhnya berasal dari Kristus. Maka bagi Gereja memelihara dan menampakkan kekudusan sangat tergantung pada kesatuannya dengan Sang Kepala Tubuh. Kesatuan dengan Kristus merupakan prinsip bagi Gereja, di luar itu Ge- reja kehilangan hakikatnya. Kesatuan Gereja dengan Kristus, terkhusus dalam komuni menjadikan Gereja sehati dan sejiwa dengan Kristus. Kesatuan yang dialami oleh Gereja dalam Ekaristi merupakan kesatuan tidak hanya dengan Kristus melainkan dengan Bapa dan Roh Kudus. Roh Kudus mengobarkan jiwa dan pikiran Gereja untuk melakukan apa yang telah dilakukan oleh Kristus. ${ }^{37}$ Roh Kuduslah yang menggerakkan Gereja untuk keluar dari dirinya sendiri. Maka Ekaristi dalam membentuk Gereja mempunyai konsekwensi sosial. Gereja tidak bisa tinggal diam berada dalam dunia yang terluka. Teladan Kristus dalam membasuh kaki kedua belas rasul menggambarkan pengosongan diri, kerendahan hati sebagai Putera Allah dan penyerahan yang total bagi terwujudnya keselamatan.

Model pelayanan Kristus ialah tidak hidup untuk diri sendiri (bdk. 2 Kor 5:15). Sikap pengosongan diri Kristus dimaknai Cantalamessa sebagai sikap yang tidak takut untuk kehilangan martabat ilahi-Nya dan tidak terlalu memperdulikan penilaian orang lain terhadap diri-Nya. Kesederhanaan Kristus merupakan gerak dasar Injil. ${ }^{38}$

Gereja berada di tengah dunia. Gereja sebagai musafir menapaki jalan kekudusan yakni dengan mencari hal-hal yang di atas di mana Kristus berada. (bdk. Mat 6:33). "Mencari hal-hal di atas" sebagai sikap mengarahkan hati dan diri pada pertemuan dengan Tuhan, menjadikan peristiwa pertemuan sebagai pusat dan mercu suar yang menerangi hidup. ${ }^{39}$ Keberadaan umat Kristiani sebagai bibit dari Allah yang ditaburkan di dunia dengan tujuan pada akhir zaman dunia menjadi kebun Allah yang menghasil-

\footnotetext{
37 Cantalamessa, Easter Meditations on the Resurrection, 24

38 Cantalamessa, The Eucharist Our Sanctification, 70.

39 Cantalamessa, The Eucharist Our Sanctification, 102.
}

\footnotetext{
3 Cantalamessa, The Eucharist Our Sanctification, 62.

Cantalamessa, The Eucharist Our Sanctification, 57.

Cantalamessa, The Eucharist Our Sanctification, 58

Cantalamessa, The Eucharist Our Sanctification, 76
} 
kan buah. ${ }^{40}$ Hikmat kristiani terdapat dalam mempergunakan hal-hal yang ada dalam dunia dengan bijaksana dan berjaga seakan besok akan ada akhirat, dan bekerja bagi dunia seakan tidak ada akhirat. ${ }^{41}$

\section{Ekaristi sebagai Jiwa Panggilan Kekudusan Gereja}

Ekaristi sebagai pusat alam ciptaan/ dunia menurut Cantalamessa berarti keberlangsungan terus menerus karya keselamatan Allah hingga saat ini. Keberlangsungan karya keselamatan tersebut secara efektif terjadi dalam diri Gereja yang mengimani dan diresapi oleh Kristus melalui Ekaristi. Melalui Gereja yang merupakan Tubuh Mistik Kristus karya keselamatan itu dialirkan kepada dunia/ alam semesta. Dalam arti ini peran Gereja sangat penting bagi dunia. Sebab melalui kesatuan Gereja dengan Kristus, Bapa melalui Roh Kudus menyalurkan rahmat bagi dunia. Di sinilah letak pentingnya partisipasi Gereja pada kekudusan Allah melalui Kristus.

Cantalamessa secara sistematis menguraikan bagaimana Gereja dijiwai oleh Ekaristi. Dua dimensi horizontal dan vertikal dialami Gereja pada saat merayakan Ekaristi yang berdaya ubah. Maka kesadaran Gereja pada partisipasinya pada kekudusan Allah sangatlah penting sementara bagi dunia dampak karya keselamatan tidak secara langsung, karena dunia tidak mempercayai Kristus. Dampak misteri keselamatan bersifat universal bukan hanya untuk sebagian manusia yang percaya kepada Kristus namun bagi seluruh umat manusia dan alam ciptaan. Misteri keselamatan bukan hanya terjadi pada masa Yesus hidup dan berkarya hingga sengsara, wafat dan kebangkitan, melainkan hingga saat ini sampai pada kepenuhan

40 Cantalamessa, The Eucharist Our Sanctification, 97.

41 Cantalamessa, The Eucharist Our Sanctification, 98. masa. Ekaristi menjadi saat yang istimewa bagi Gereja. Sebagai sakramen, Ekaristi senantiasa menghadirkan serta mengenangkan Misteri keselamatan Allah melalui Kristus.

Ekaristi sebagai akar dari segala bentuk kekudusan menurut pandangan Raniero Cantalamessa merupakan sebuah proses terus menerus Gereja menjadi semakin serupa dengan Kristus. Proses tersebut dicapai dengan dua cara sekaligus. Pertama, melalui iman Gereja dipersatukan melalui sakramen-sakramen, terkhusus Ekaristi. Kedua melalui persatuan dengan Kristus, Gereja diutus menguduskan dunia melalui tindakan-tindakan yang diwariskan-Nya.

Ekaristi sebagai akar dari setiap bentuk kekudusan bagi Cantalamessa berarti bahwa Gereja mendapat nutrisi-nutrisi ilahi, bertumbuh dan dibentuk menjadi pohon yang kokoh kuat, tempat di mana dunia mengalami kehadiran Roh Kudus dan kehadiran Allah di tengah-tengah manusia (bdk. 1Kor 14:25). Metafora akar bagi Cantalamessa menggambarkan sentralitas dan hakikat Ekaristi sebagai sakramen yang menopang kehidupan Gereja yang sedang berziarah di dunia. Panggilan kepada kekudusan bagi Gereja merupakan buah dari pengudusan Kristus yang terus menerus diperbarui dalam Sakramen Ekaristi. Kualitas akar yang kokoh menopang pertumbuhan Gereja dalam menghadapi tantangan-tantangan. Bersama dan di dalam Kristus Gereja mengudusakan dunia dalam kerangka sejarah keselamatan.

\section{PAUS BENEDIKTUS XVI: KRISTUS SEBAGAI TITIK PANGKAL KEKUDUSAN GEREJA}

Paus Benediktus XVI, adalah seorang akademisi, teolog dan filsuf. Latar belakang 
pandangannya banyak dipengaruhi oleh studi di sekolah Tinggi Filsafat dan Teologi Universitas Munich yang menekankan aspek alkitabiah, liturgis dan ekumenis. Sebagai kardinal dan paus, Benediktus XVI banyak menggeluti ajaran ajaran doktrinal Gereja.

Dalam studi historis dan teologis Blanco Sarto atas pemikiran Benediktus, tema sentral yang ia temukan adalah kehadiran Kristus dalam Ekaristi dan liturgi serta hubungannya dengan Gereja. ${ }^{42}$ Dalam membangun refleksi teologis, ia selalu bertolak dari Kristus. Baginya Kristus adalah Allah yang benar dan manusia yang sejati. ${ }^{43}$ Kristus menjadi dasar dalam membangun iman yang mendasar bagi Gereja. Di dalam Kristus Umat Allah disatukan dan menjadi keluarga Kerajaan Allah. ${ }^{44}$

Berpangkal pada titik tolak pandangan teologis Benediktus XVI, ia menguraikan pandangannya tentang kekudusan Gereja. Kekudusan adalah panggilan utama (ultimate calling) bagi Gereja apapun bentuknya. Di dalam audiensinya di Basilika St. Petrus pada tahun 2011, Paus Benediktus XVI secara khusus menjelaskan makna, dasar dan konsekuensi kekudusan bagi umat Katolik. ${ }^{45}$ Panggilan kepada kekudusan bagi Gereja berarti persatuan dengan Kristus sebagai keluarga Allah. ${ }^{46}$ Yesus Kristus adalah titik pangkal kekudusan Gereja, sebab di dalam diri-Nya seluruh misteri kasih Allah mendapat kepenuhannya (bdk. Kol

\footnotetext{
42 Blanco Sarto, "A symphonic synthesis, The theological thouch of Joseph Ratzinger/ Benedict XVI," ET-Studies 9/1 (2018), 117.

43 J. Ratzinger, "These for Christology", 119-120; J. Ratzinger, "What Does Jesus Christ Mean to Me?", 122.

44 Joseph Ratzinger, Christian Brotherhood (London and Melbourne: Sheed \& Ward/Stagbooks, 1966), 49.

45 Benedict XVI, General Audience, St. Peter's, 1 (November 2011), tersedia dari http://w2.vatican.va/content/benedict-xvi/en/ messages/lent/documents/hf_ben-xvi_mes_20111103_lent2012.pdf, diakses 13 Maret 2019.

46 Joseph Ratzinger, Christian Brotherhood, 49.
}

1:19) ${ }^{47}$ Allah melalui Kristus menjadi dekat dengan manusia, nyata dan dapat didengar, sehingga dari diri-Nya Gereja mengalami kepenuhan rahmat dan kebenaran-Nya (bdk. Yoh 1:14-16).

Dalam menghayati panggilannya kepada kekudusan Benediktus menegaskan pentingnya persatuan dengan Kristus. Ia memberikan contoh partisipasi Gereja dalam kekudusan di sepanjang sejarah melalui kesaksian hidup para kudus. Dengan cara hidupnya yang khas, para kudus mengungkapkan buah dari transformasi perjumpaan dengan Kristus yang bangkit (bdk. LG. 40). Melalui para kudus Kerajaan Allah menjadi terang kehidupan, yang bertentangan dengan penghancuran umat manusia oleh karya kuasa jahat. ${ }^{48}$

Kata kunci dalam memahami dan menghayati panggilan kepada kekudusan seperti dicontohkan Benediktus adalah kesatuan yang mesra dengan Kristus. Di dalam kesatuan tersebut Gereja mendapatkan bagian dari kodrat ilahi, sehingga karenanya Gereja dikuduskan (bdk. LG. 40). Dampak dari kesatuan dengan Kristus yakni Gereja mengalami misteri-Nya dalam bentuk keteladanan tindakan, cara berpikir, dan melakukan ajaran-ajaran Kristus. Ukuran ambil bagian kepada kekudusan Gereja terletak pada buah transformasi dari persatuannya dengan Kristus, yakni semakin serupa dengan Kristus (bdk. Rm. 8:29). Misteri Kristus yang begitu agung tersebut menjadi pondasi sekaligus jiwa Gereja.

\footnotetext{
47 Benedict XVI, General Audience, St. Peter's Square (April $2011), 2$.

48 Robert Moynihan, Let God's Light Shine Forth, The Spiritual Vision of Pope Benedict XVI (London: Hutchinson, 2005), 169170.
} 


\section{Ekaristi: Akar dari Segala Bentuk Kekudusan Gereja}

Bagi Benediktus, Gereja merupakan persekutuan Umat Allah yang berpusat pada meja perjamuan dengan Kristus yang bangkit. ${ }^{49} \mathrm{Hal}$ ini menurut penulis menunjuk pada Ekaristi. Hubungan antara Gereja dan Ekaristi dalam pandangan Benediktus XVI merupakan hal yang esensi, sebab berhubungan dengan keberlangsungan hidup Gereja di dunia. Dalam seruan apostoliknya yang pertama, Sacramentum Caritatis art. 94 Benediktus menyerukan esensi Ekaristi bagi perutusan Gereja di dunia demikian:

Saudara-saudari terkasih, Ekaristi adalah akar dari setiap bentuk kesucian, dan setiap orang dari kita dipanggil kepada kepenuhan hidup dan Roh Kudus. Betapa bayak orang kudus telah meniti jalan kesempurnaan serta terbantu oleh devosi Ekaristi mereka!. Kekudusan mereka selalu menemukan pusatnya dalam Sakramen Ekaristi [...] Persembahan hidup kita, persekutuan kita dengan seluruh komunitas orang beriman, dan solidaritas kita dengan semua orang merupakan segi hakiki dari logike latreia, ibadat rohani, yang kudus dan berkenan kepada Allah (bdk. Rm. 12:1), yang mengubah setiap segi keberadaan manusiawi kita menjadi kemuliaan Allah. ${ }^{50}$

Panggilan Gereja kepada kekudusan di dunia yang berpusat pada Sakramen Ekaristi dalam pandangan Benediktus mempunyai tiga makna teologis. Pertama, kesatuan yang berdampak asimilasi/ peleburan hidup Gereja dengan Kristus; kedua, Gereja disatu-

49 Joseph Ratzinger, "On the Spirit of Brotherhood", dalam Dogma and Preaching: Benedict XVI-Joseph Ratzinger, ed. M.J. Miller (San Francisco: Ignatius Press), 2011, 208.

50 Benediktus XVI, Sacramentum Caritatis ( 22 Februari 2007), art 94. (http://w2.vatican.va/content/benedict-xvi/en/apost_ exhortations/documents/hf_ben-xvi_exh_20070222_sacramentum-caritatis.html); diakses 11 Juni 2019. kan dengan anggota Tubuh Mistik Kristus yang lain sebagai communio; ketiga, penghayatan Gereja akan hidup sebagai persembahan kepada Allah. Analogi akar menunjukkan bahwa Ekaristi menjadi penopang kehidupan Gereja di dunia. Daripadanya Gereja mendapat bentuk dan roh dari Kristus dalam peziarahannya di dunia.

Persatuan Gereja dengan Kristus melalui Ekaristi, berdampak peleburan hidup Gereja. Tubuh dan darah Tuhan memberikan nutrisi bagi kelangsungan hidup Gereja di dunia (bdk. S.Car 9). Dengan makan roti Ekaristi, yang merupakan Tubuh Tuhan Gereja diubah menjadi serupa dengan Kristus, ${ }^{51} \mathrm{Ge}$ reja diasimilasikan/ dilebur dengan seluruh diri Yesus. Kata 'tubuh' dalam bahasa Kitab Suci menunjuk pada keseluruhan pribadi seseorang (tubuh dan rohnya) yang tidak terbagi satu dengan yang lain. ${ }^{52}$

Kehadiran Kristus yang nyata dalam Ekaristi (realis praesentia) tidak dapat dilepaskan dari gagasan transubstantiatio, perubahan roti dan anggur menjadi tubuh dan darah Tuhan. Selain itu, terdapat empat proses trasformasi dalam diri Gereja yang merayakan Ekaristi yakni transformasi dari kekerasan ke tindakan kasih, transformasi dari budaya kematian ke kehidupan, transformasi Gereja menjadi satu tubuh dengan Kristus dan transformasi ciptaan sebagai tempat bagi Allah. ${ }^{53}$ Maka Ekaristi bersifat kosmis, artinya Ekaristi selalu dirayakan di atas altar dunia. Dengan dirayakan di atas altar dunia, Ekaristi menyatukan surga dan dunia. Ekaristi merangkul semua ciptaan. Melalui Ekarsiti kerusakan dunia akibat

\footnotetext{
51 Robert Moynihan, Let God's Light Shine Fort, The Spiritual Vision of Pope Benedict XVI (London: Hutchinson, 2005), 115.

52 Joseph Ratzinger, God is Near Us: The Eucharist, the Heart of Life, 79.

53 Joseph Ratzinger, "Eucharist, Communion, and Solidarity," 8184
} 
dosa ditebus dan dipulihkan oleh Kristus. ${ }^{54}$ Dengan demikian Ekaristi tidak hanya menguduskan manusia (dalam arti Gereja) namun juga menguduskan alam semesta yang telah diciptakan Allah baik adanya.

Hidup Gereja yang ditransformasi oleh Kristus menggerakkan Gereja untuk bergerak keluar dari dirinya menjumpai sesama, seperti Kristus bergerak turun ke dunia untuk menjumpai manusia. Asimilasi hidup Kristus mengandung perutusan bagi Gereja untuk turut ambil bagian dalam karya keselamatan Kristus yang berlangsung saat ini hingga pada kepenuhan masa. Dampak Ekaristi bagi kekudusan Gereja bagaikan pecahan nuklir yang dapat merasuk ke dalam jiwa manusia seperti yang tertulis dalam Sacramentum Caritatis no 11:

Perubahan substansial roti dan anggur menjadi tubuh dan darah menampilkan asas perubahan radikal sejenis "pemecahan nuklir", untuk menggunakan gambaran yang familiar untuk kita sekarang. Perubahan itu merasuk ke dalam jantung segala mahluk, menimbulkan proses yang mengubah realita, suatu proses yang secara total mengantar kepada perubahan seluruh dunia, sampai pada titik di mana Allah akan menjadi semua di dalam semua. (bdk. 1Kor 15:28)

Penyerahan diri Allah yang diterima dalam Ekaristi mendorong Gereja untuk memberikan dirinya bagi dunia. Asimilasi hidup Kristus menjadi misi dan visi hidup Gereja, sebuah proses yang mengubah realita. Hidup Gereja yang telah ditransformasi oleh hidup Kristus merupakan jiwa kekudusan.

54 Philip Khights, "The Whole Earth My Altar"; A Scramental Tra jectory for Ecological Mission," Mission Studies Vol. 25, No. 1 (2008), 58
Selain dipersatukan dengan Kristus, dalam Ekaristi Gereja dipersatukan dengan komunitas umat beriman lainnya. Sebagai perayaan bersama (communio), Ekaristi dirayakan secara benar apabila dirayakan dalam kebersamaan seluruh Gereja. ${ }^{55}$ Ekaristi menjadi jaminan persatuan umat Allah di seluruh dunia. Realitas ini menjadi realitas metafisik yang melampaui batas waktu dan ruang, bahwa Kristus dan seluruh anggota Tubuh Mistik-Nya tidak terpisahkan karena Ekaristi. ${ }^{56}$ Hakikat Gereja bukanlah bersifat individual, Gereja merayakan misteri cinta kasih Allah dalam Ekaristi dengan yang lain. Maka kekudusan Gereja senantiasa dibarui dalam kebersamaan dengan yang lain.

Ekaristi mencakup kehidupan nyata Gereja hari demi hari. Ekaristi memungkinkan perubahan bertahap semua orang yang dipanggil oleh rahmat untuk menjadi serupa dengan Putra Allah (bdk. Rm. 8:29). Dalam kesatuan dengan Kristus dan anggota Tubuh Mistik-Nya hidup Gereja menjadi sebuah persembahan yang hidup. Benediktus menyebutkan penghayatan Gereja akan hidup sebagai sebuah persembahana kepada Allah adalah, segi hakiki dari logike latreia, ibadat rohani, yang kudus dan berkenan kepada Allah (bdk. Rm. 12:1). Oleh karena itu pancaran peribadatan Gereja adalah pantulan kemuliaan Allah dan manusia adalah penampakan Allah (S.Car. 71). Sakramen Ekaristi mengubah yang insani dalam diri Gereja menjadi Ilahi. Inilah yang dimaksud Benediktus akan kebaruan yang radikal yang dibawa oleh Kristus dalam Ekaristi (S.Car. 71). Melalui Ekaristi, Gereja sebagai Tubuh Mistik Kristus menjadi saluran rahmat bagi dunia. ${ }^{57}$

55 Joseph Ratzinger, God is Near Us: The Eucharist, the Heart of Life, 120.

56 Marcus Benedict, "The Eucharist Christology of Pope Benedict XVI" (Januari 2019), tersedia dari https://www.hprweb. com/2019/01/the-eucharistic-christology-of-pope-benedict-xvi/; diakses 25 April 2019.

57 John Anthony Berry, "From the open side of the Lord: on Jo- 


\section{Ekaristi, Sakramen Cinta kasih Allah bagi Gereja}

Bapa Suci sering menyebutkan Sakramen Ekaristi dalam hubungannya dengan kasih Gereja terhadap Allah maupun sesama. Di dalam Ekaristi manusia secara langsung dapat menerima kasih agape Allah (S.Car. 5). Benediktus XVI menyebut sakramen Ekaristi sebagai Sakramen Cinta Kasih karena pada hakikatnya Kasih Allah yang memberikan diri seutuhnya itu tidak hanya terjadi dalam sejarah namun terus lestari dalam Sakramen Ekaristi. Gereja yang telah menerima dan dipersatukan dengan Allah melalui sakramen Ekaristi, bukan hanya menerima tubuh dan darah Tuhan melainkan menerima pula penyerahan diri Allah. ${ }^{58}$

Ekaristi dalam kehidupan Gereja adalah sakramen yang esensi, sebab melalui Ekaristi yang kekal masuk ke dalam saat ini melalui tindakan liturgi. ${ }^{59}$ Kristus sebagai subyek liturgi sekaligus pusat perayaan, ${ }^{60}$ maka Gereja tidak dapat bertindak dalam liturgi tanpa dan bersama Kristus. ${ }^{61}$ Kekayaan dan kedalaman Ekaristi yang menjadi magisterium Benediktus XVI dalam Sacramentum Caritatis tampak dalam tiga aspek yang saling terhubung. Tiga aspek tersebut yakni Misteri Ekaristi, tidakan liturgi dan ibadat spiritual baru. Menurut Kardinal Angelo Scola tiga aspek tersebut adalah poros yang menjadi tumpuan seluruh ajaran Bapa

seph Ratzinger's Eucharistic Ecclesiology",

58 Ratzinger, Pilgrim Fellowship of Faith, 102.

59 Joseph Laramie, "The Eucharist Exercises: Using the concept of raditus, as explicated in Benedict XVI," Disertasi, Boston College Electronic, 2012, 31.

The Eucharist is "the entry of the eternal into our present moment in the liturgycal action."

60 Joseph Ratzinger, The Feast of Faith, 25-26.

61 Joseph Ratzinger, Theology of the Liturgy: Lecture Delivered During the Journess Liturgiques de Fontgombault", dalam The Essential Pope Benedict XVI: His Central Writings and Speeches, eds. J.F Thonton dan S.B Varenne (Harper Collins e-book), 153.
Suci. ${ }^{62}$ Secara khusus Benediktus XVI menguraikan keagungan Ekaristi dalam Sacramentum Caritatis sebagai akar kekudusan dalam tiga tema besar yakni, pertama, Ekaristi Misteri untuk diimani, kedua Ekaristi Misteri untuk dirayakan dan ketiga Ekaristi, Misteri untuk dihayati. Dengan menguraikan tiga tema besar dalam seruan Apostoliknya diharapkan memberikan arahan mendasar untuk membarui komitmen umat kristiani serta mengobarkan antusiasme dan gairah ekaristis dalam Gereja (S. Car, 5).

\section{Ekaristi, Misteri untuk Diimani}

Ekaristi sebagai Misteri yang diimani dimaksudkan sebagai tanggapan Gereja akan Kristus yang senantiasa berinisiatif untuk menghidupi Gereja dengan Roh-Nya. Iman Gereja akan Kristus dalam Ekaristi menjadi dinamika yang terus menjaga kesatuan tanpa dibatasi oleh ruang dan waktu. Dengan demikian melalui Ekaristi Kristus melembagakan Kasih dalam pemberian diri-Nya kepada Gereja dari zaman ke zaman.

Benediktus mengungkapkan bahwa Ekaristi adalah pusat iman dan jantung Gereja. Perubahan substansial roti dan anggur menjadi Tubuh dan Darah Tuhan menunjukkan asas perubahan radikal yakni perubahan yang merasuk ke dalam jantung segala mahluk, menimbulkan proses yang mengubah realita sampai pada titik di mana Allah akan menjadi semua di dalam semua (bdk. 1Kor. 15:28; S.Car. 11). Di sini tampak mengapa Gereja perlu mengungkapkan imannya dalam ritus, yakni perayaan iman seluruh umat beriman yang berkumpul dalam persekutuan dengan Allah. ${ }^{63}$ Di dalam Sacramentum Caritatis art. 6 dituliskan bahwa terdapat

\footnotetext{
62 Cardinal Angelo Scola, Commentary on the Apostolic Exhortation Sacramentum Caritatis

63 Krispurwana Cahyadi, Benediktus XVI, (Yogyakarta: Kanisius, $2010), 87$.
} 
hubungan timbal balik antara ritus dan pertumbuhan iman Gereja. Melalui ritus, Gereja mengungkapkan imannya dan dari ritus, iman Gereja dikuatkan dan diteguhkan.

Keunggulan iman Gereja pada Ekaristi terletak pada partisipasi Gereja masuk dalam misteri kasih tritunggal (S.Car.8). Partisipasi berkat rahmat Allah ini memungkinkan pembaruan yang senantiasa terjadi setiap kali Ekaristi dirayakan, setiap kali Gereja menemukan iman akan keagungan Ekaristi serta menyatakan seluruh sejarah keselamatan (S.Car.8).

Iman akan misteri Ekaristi adalah iman akan kasih Trinitas. Kasih Trinitas tersebut ditunjukkan dalam kasih Bapa kepada dunia, penyerahan Putera-Nya bagi rencana karya keselamatan serta karya Roh Kudus sebagai penjamin terlaksananya rencana agung tersebut (bdk. Yoh 3:16-17). Melalui Ekaristi Sang Putera menyerahkan diri dan hidupNya kepada Gereja sebagai makanan (S.Car. 7). Dalam Sacrosantum Concilium art. 7 dituliskan bahwa Liturgi dipandang bagaikan pelaksanaan tugas imamat Yesus Kristus; di situ pengudusan manusia dilambangkan dengan tanda-tanda lahir. Dalam Ekaristi Yesus menggunakan roti dan anggur untuk memberikan diri-Nya kepada Gereja dalam Roti yang telah Ia ubah menjadi Tubuh-Nya Gereja berjumpa dengan seluruh kehidupan Allah. Secara sakramental kehidupan Allah dibagikan melalui daya Roh Kudus yang memungkinkan Gereja memiliki kehidupan batin Allah. Roh Kudus menghadirkan Kristus untuk melanjutkan kehadiran dan kegiatan-Nya dalam Gereja-Nya, mulai dari jantung hidupnya yakni Ekaristi (S.Car. 12). Dengan demikian Ekaristi membuat Gereja ambil bagian dalam kehidupan Allah sendiri.

Gereja mengimani Misteri Paskah dalam Ekaristi artinya Gereja mengimani keku- dusan yang terus berlangsung dari zaman ke zaman. Melalui Kristus yang memberikan diri dalam Ekaristi Gereja mengalami kasih Trinitas. Kekudusan dalam pandangan Benediktus adalah transformasi Gereja dengan kasih Trinitas tersebut. Maka iman merupakan pintu bagi Gereja untuk menanggapi tawaran kekudusan Allah. Tanggapan Gereja akan tawaran kekudusan Allah tampak dalam pengungkapan imannya dalam perayaan.

\section{Ekaristi, Misteri untuk dirayakan}

Ekaristi sebagai Misteri yang dirayakan dimaksudkan sebagai perayaan karya kekudusan umat manusia dan pemuliaan Allah. Kekudusan umat manusia dan pemuliaan Allah merupakan realitas keselamatan yang dilihat dari dua segi. Pertama dari pihak Allah kepada manusia, terlaksana penebusan atau pengudusan umat manusia. Kedua dari pihak manusia kepada Allah, terjadilah pemuliaan Allah. ${ }^{64}$

Iman Gereja dan liturgi ekaristis bersumber pada peristiwa pemberian diri Kristus dalam Misteri Paskah (S.Car. 34). Benediktus menjelaskan hubungan hakiki antara iman dan Parayaan Ekaristi. "Ekaristi hendaknya dihayati sebagai suatu misteri iman, yang dirayakan secara autentik dan dengan kesadaran yang jelas bahwa "intelectus fidei" (pengetahuan iman) memiliki hubungan asali dengan kegiatan liturgis Gereja" (S.Car. 34). Maka sangat disarankan agar umat Allah memahami dengan sungguh akan misteri agung Ekaristi. Sebab di dalam Ekaristi kebenaran kasih Allah dalam Kristus menjumpai Gereja, menarik Gereja, dan menggembirakan hati Gereja, sambil membuat Gereja mampu keluar dari dirinya sendiri dan menarik Gereja menuju pang-

64 E. Martasudjita, Liturgi, Pengantar untuk Studi dan Praksis Liturgi (Yogyakarta: Kanisius, 2011 ), 26. 
gilan yang sejati yakni kasih. Sebab Kristus adalah penampakan sempurna kemuliaan Allah (S.Car. 35).

Liturgi Ekaristi pada hakikatnya adalah actio Dei (tindakan Allah) yang menarik Gereja kepada Kristus melalui Roh Kudus (S. Car. 37). Sebagai perayaan puncak, Benediktus XVI menekankan partisipasi aktif (participatio actuosa) dalam liturgi seperti yang dianjurkannya dalam seruan apostolik art. 66: Hendaknya dijelaskan bahwa kata 'partisipasi' tidak hanya merujuk kepada aktivitas lahiriah selama perayaan. Tetapi, partisipasi aktif yang ditonjolkan oleh konsili harus dipahami dalam arti yang substansial, berdasarkan kesadaran yang lebih besar akan misteri yang sedang dirayakan dan hubungannya dengan hidup sehari-hari. Dalam konteks perayaan liturgi, partisipasi aktif menuntut tindakan umat Allah yang berangkat dari penghayatan iman yang benar. Ketika umat Allah hanya melakukan ritus liturgi dalam taraf mematuhi aturan dan hanya pada tingkat 'ekspresi' maka sebuah perayaan liturgi dihadiri oleh 'pemain'. ${ }^{65}$ Partisipasi aktif menuntut kesadaran pribadi sebagai bagian utuh dari perayaan liturgi dan berdampak dalam hidup sehari-hari.

Dalam buku The Feast of Faith, Paus Benediktus XVI menjelaskan dua elemen pokok dalam partisipasi aktif umat (partisipatio actuosa). ${ }^{66}$ Elemen pertama adalah keheningan. Dalam keheningan kata dan tanda liturgis membawa umat untuk berjumpa dengan Sang Sabda, Sabda kasih yang tersalib dan bangkit dan membuahkan kehidupan dan sukacita. ${ }^{67}$ Elemen kedua adalah sikap atau tata gerak umat Allah yang menghayati dan mengungkapkan pujian pada Allah. ${ }^{68}$

65 Joseph Ratzinger, The Feast of Faith, 69.

66 Joseph Ratzinger, The Feast of Faith, 72-73.

67 Joseph Ratzinger, The Feast of Faith, 73.

68 Joseph Ratzinger, The Feast of Faith, 73-74.

\section{Ekaristi, Misteri untuk Dihayati}

Dengan menghayati Ekaristi, Gereja menghayati pemberian diri Kristus bagi kelangsungan kehidupannya di dunia. "Ia yang memakan Aku, akan hidup oleh Aku" (Yoh 6:57). Kelangsungan hidup Gereja secara khas tampak dalam partisipasinya mewartakan kerajaan Allah di dunia. Sebab dengan menerima Tubuh dan Darah Kristus Gereja ambil bagian dalam keilahian Kristus. Ekaristi menjadi jaminan persatuan, baik antara Kristus dan Tubuh Mistik-Nya maupun antara umat Allah di seluruh dunia. Realitas ini menjadi realitas metafisik yang melampaui batas waktu dan ruang fisik, bahwa Kristus dan seluruh anggota Tubuh Mistik-Nya tidak terpisahkan karena Ekaristi. ${ }^{69}$

Penghayatan Gereja akan kesatuannya yang tidak terpisahakan dengan Kristus dalam Ekaristi memberi dampak pada kesaksian hidup di dunia. Dengan menjadi makanan Kristus Tuhan mengasimilasi Gereja ke dalam diri-Nya yang mulia dan menjadi satu Tubuh. ${ }^{70}$ Kristus, melalui Ekaristi bagaikan mempelai pria bagi Gereja (bdk. 1Kor 12). hal ini menggambarkan realitas metafisik antara Sakramen Ekaristi dan Gereja. Paus Benediktus XVI sebagaimana mengutip ajaran St. Agustinus dalam seruan apostolik Sacramentum Caritatis art. 70 dengan mengatakan: Bukan santapan Ekaristi yang berubah menjadi diri kita, tetapi sebaliknya kitalah yang secara misterius diubah olehnya. Kristus memupuk kita dengan menyatukan kita dengan diri-Nya, "Ia merengkuh kita dalam diri-Nya". Dengan demikian yang ada dalam Tubuh Mistik Yesus Kristus bukanlah

69 Marcus Benedict, "The Eucharist Christology of Pope Benedict XVI," (Januari 2019), tersedia dari https://www.hprweb. com/2019/01/the-eucharistic-christology-of-pope-benedict-xvi/; diakses 25 April 2019.

70 Pope Benedict XVI, Sant Paul (San Fransisco: Ignatius Press, 2017), 121. 
susunan organisasi melainkan satu jaringan organisme..$^{71}$

\section{Ekaristi sebagai Perayaan Jiwa Kekudusan Gereja}

Bagi Paus Benediktus XVI Sakramen Ekaristi merupakan pusat kekudusan. Menurut penulis terdapat dua penekanan dalam memaknai Ekaristi sebagai akar. Pertama, dalam Ekaristi umat Allah dihantar untuk lebih dekat dengan kasih Allah, serta diundang untuk terlibat/ berpartisipasi dalam karya keselamatan Allah dalam diri Yesus Kristus dengan mengenangkan sengsara, wafat dan kebangkitan-Nya. Partisipasi yang dimaksud Paus Benediktus XVI adalah keterlibatan dalam lingkaran Trinitas. Bapa mengutus Putera untuk melaksanakan rencana keselamatan dan Roh Kudus sebagai penjamin hadirnya karya keselamatan. Gereja dengan sakramen yang diterima dimasukkan dalam lingkaran karya keselamatan Allah tersebut. Kedua, Ekaristi mempersatukan umat Allah menjadi komunitas, tempat saling memberikan diri dan wujud ibadat rohani yang kudus dan berkenan kepada Allah. Dalam ajarannya, tampak segi penghayatan Ekaristi dalam liturgi berdampak ke luar yakni dalam membangun hidup berkomunitas yang saling terlibat satu dengan yang lain.

\section{SINTESA PANDANGAN TEOLOGI RANIERO CANTALAMESSA DAN PAUS BENEDIKTUS XVI}

Kesamaan dan perbedaan pandangan teologis Cantalamessa dan Benediktus XVI, menurut penulis saling membangun dan memperkuat teologi Ekaristi sebagai akar dari segala bentuk kekudusan. Kesamaan pandangan Raniero Cantalamessa dan Paus
Benediktus XVI tentang makna kekudusan dapat dijelaskan sebagai berikut. Pertama, kekudusan berasal dari Allah. Kekudusan merupakan anugerah dari Allah yang bersifat tetap namun dibutuhkan usaha dari pihak manusia untuk terus memelihara. Secara khusus Cantalamessa dan Benediktus XVI memberi penekanan bahwa meski kekudusan dimiliki oleh setiap manusia namun bagi Umat Allah sakramen Baptis dan Ekaristi mempunyai peranan yang sentral bagi kekudusan Gereja.

Kedua, Ekaristi sebagai akar kekudusan Gereja. Persamaan pandangan yang sangat mendasar bagi kedua tokoh adalah di dalam Ekaristi Gereja mendapatkan nutrisi-nutrisi untuk penjamin kehidupan Gereja. Ekaristi merupakan Roh atau jiwa Gereja, sebab secara langsung Gereja dapat berkomunikasi dengan Allah melalui Kristus dan Kristus menstransformasikan diri-Nya ke dalam Gereja. ${ }^{72}$

Perbedaan pertama pandangan kedua tokoh tampak dalam metodologi. Cantalamessa begitu kuat menggunakan pandangan Bapa-Bapa Gereja atau Patristik, sementara Benediktus XVI kuat memakai Kitab Suci sebagai titik tolak ajarannya. Benediktus dikenal sebagai teolog yang mengembangkan gagasan kembali ke akar teologi yakni Kitab Suci dan magisterium.

Perbedaan kedua, dari penekanan ajaran. Cantalamessa dalam pandangannya menekankan karya Roh Kudus atau aspek pneumatologis dan ekklesiologis, sementara Benediktus XVI pada aspek kristologis dan liturgis. Bagi Cantalamessa Roh Kristus adalah cinta dan menumbuhkan kesatuan dan menanamkan kebaikan. Sebab Roh Kudus itu sendiri merupakan Tubuh Kristus yang merupakan kesatuan. Roh Kudus 
yang menguduskan manusia, memungkinkan manusia untuk diam di dalam Allah dan Allah diam di dalam manusia. Daripada-Nya manusia dikuduskan di dalam Kristus Yesus (1Kor 1:2). ${ }^{73}$ Dengan demikan menurut pandangan Cantalamessa berkat karya Roh Kudus Kristus membangun Gereja.

Sentralitas ajaran dan pandangan teologis Benediktus XVI adalah kehadiran Kristus dalam Ekaristi dan liturgi. ${ }^{74}$ Dalam membangun refleksi teologis, Benediktus XVI selalu bertolak dari Kristus. Iman akan Kristus menjadi pangkal sekaligus akar dalam membangun gagasan teologis. Bagi Benediktus XVI Kristus adalah Allah yang benar dan manusia yang sejati. Kristus menjadi dasar dalam membangun iman yang mendasar bagi umat Kristiani. Di dalam Kristus Umat Allah disatukan dan menjadi keluarga Kerajaan Allah. ${ }^{75}$ Misteri Kristus yang begitu agung tersebut menjadi fondasi sekaligus jiwa Gereja hingga saat ini melalui Ekaristi. Gereja sebagai Tubuh Kristus merupakan saluran rahmat bagi dunia. ${ }^{76}$

73 Cantalamessa, Jesus Christ, The Holy One of God, 20.

74 Blanco Sarto, "A symphonic synthesis, The theological thouch of Joseph Ratzinger/ Benedict XVI," ET-Studies 9/1 (2018), 117.

75 J. Ratzinger, Christian Brotherhood (London and Melbourne: Sheed \& Ward/ Stagbooks, 1966), 49.

76 John Anthony Berry, "From the open side of the Lord: on Joseph Ratzinger's eucharistic ecclesiology", The Quest for Authenticity and Human Dignity, tersedia dari https://www. researchgate.net/publication/318641372_From_the_open_ side_of_the_Lord_On_Joseph_Ratzinger's_Eucharistic_Ecclesiology, diakses 4 Juni 2019.

\section{DAFTAR PUSTAKA}

Anderson, Alan L. "ACurious Absencein Gaudate et Exsultate", April 2018; Tersedia dari https:// www.thecatholicthing. org/2018/04/15/acurious-absence-in-gaudete-et-exsultate/; diakses 11 Mei 2018.

Benedict XVI, General Audience , St. Peter's, 1 (November 2011), tersedia dari http:// w2.vatican.va/content/benedict-xvi/en/ messages/lent/documents/hf_ben-xvi mes_20111103_lent-2012.pdf, diakses $1 \overline{3}$ Maret 2019.

Saint Paul. San Fransisco: Ignatius Press, 2017.

\section{PENUTUP}

Misteri Ekaristi, Allah yang senantiasa membuka dirinya untuk bersatu dengan umat-Nya bukan hanya sebagai model pengudusan Gereja seperti dikatakan oleh Cantalamessa, melainkan sebagai sumber kekudusan itu sendiri. Sebab dalam Ekaristi Allah menghampiri umat-Nya. Di dalam Ekaristi Allah dalam diri Kristus senantiasa mentransformasi hidup-Nya melalui sabda dan kesatuan-Nya dengan Gereja melalui komuni kudus. Maka buah dari penghayatan Ekaristi sebagai akar dari pengudusan adalah keberanian untuk mewartakan Injil kepada dunia, melayani sesama dengan semangat tanpa dihalangi oleh keterbatasan-keterbatasan diri maupun faktor luar. Kekudusan yang berakar pada Ekaristi senantiasa mendorong Gereja untuk keluar dari diri-Nya, keluar dari kemapanan sebab Kristus senantiasa memecahkan diri-Nya untuk dapat mewartakan Kerajaan Allah dan menyelamatkan makhluk ciptaan serta mengembalikan martabat manusia maupun alam ciptaan yang telah rusak.

. "The Eucharist Christology of Pope Bene- dict XVI" (Januari 2019), tersedia dari https://www.hprweb. com/2019/01/ the-eucharistic-christology-of-pope-benedict-xvi/; diakses 25 April 2019.

"The Eucharist Christology of Pope Benedict XVI," (Januari 2019), tersedia dari https://www.hprweb. com/2019/01/ the-eucharistic-christology-of-pope-benedict-xvi/; diakses 25 April 2019.

Sacramentum Caritatis ( 22 Februari 2007), art 94. (http://w2.vatican.va/content/benedict-xvi/en/apost_ exhortations/ 
documents/hf_ben-xvi_exh_20070222_sacra- mentum-caritatis.html); diakses 11 Juni 2019.

Berry, John A. "From the open side of the Lord: on Joseph Ratzinger's eucharistic ecclesiology", The Quest for Authenticity and Human Dignity, tersedia dari https://www. researchgate.net/publication/318641372_ From_the_open_side_of_the_Lord_On_Joseph_Ratzinger's_Eücharistic_Ecclesiology, diakses 4 Juni 2019

Blanco Sarto, Blanco. "A symphonic synthesis, The Theological Thouch of Joseph Ratzinger/ Benedict XVI," ET-Studies 9/1 (2018).

Cantalamessa, R. Jesus Christ, The Holy One of God, diterjemahkan oleh Alan Neame. Collegevile: Liturgical Press, 1991.

Loving the Church: Scriptual Meditations for the Papal Household. U.S.A.: St. Anthony Messenger Press, 2005.

The Eucharist Our Sanctification, translated by Frances LonerganVilla. Collegeville, Minnesota: The Liturgical Press, 1993.

The Mystery of the Transfiguration. Cincinnati, Ohio: St. Anthony Messenger Press, 2008.

This is My Body: Eucharistic Reflections Inspired by Adoro Te Devote and Ave Verum. Boston: Pauline Books and Media, 2005.

Donio, Frank. "Gaudate et Exsultate: The Call to Holiness in Today's World”, April 2018, tersedia dari https://www.catho $\neg$ licapostolatecenter.org/blog/gaudete-et-exsultatethe-call-to- holiness-in-todays-world; diakses 10 Mei 2018.

E. Martasudjita, Ekaristi, Tinjauan Teologis, Liturgis, dan Pastoral. Yogyakarta: Kanisius, 2005.
, Liturgi, Pengantar untuk Studi dan Praksis Liturgi. Yogyakarta: Kanisius, 2011.

Fransiskus, Gaudete et exsultate (19 Maret 2018). Padraig McCormack, Ireland: Veritas Puplications, 2018.

John Paul II, General Audience 8 April 1992, tersedia dari https://adoremus.org/2007/12/31/ Catechesis-of-His-Holi- ness-John-Paul-IIon-the-Eucharist/; diakses 11 Mei 2018.

Kimbrough Jr., S.T. Holiness in The Perspective of Eucharistic Theology. Orthodox and Wesleyan Spirituality, SVS Press, 2002.

Krispurwana Cahyadi, Benediktus XVI. Yogyakarta: Kanisius, 2010.

Laramie, J. "The Eucharist Exercises: Using the concept of raditus, as explicated in Benedict XVI,” Disertasi, Boston College, 2012.

Moynihan, R. Let God's Light Shine Forth, The Spiritual Vision of Pope Benedict XVI. London: Hutchinson, 2005.

Philip Knights, "The Whole Earth My Altar"; A Scramental Trajectory for Ecological Mission," Mission Studies Vol. 25, No. 1 (2008)

Ratzinger, J. "On the Spirit of Brotherhood", dalam Dogma and Preaching: Benedict XVI-Joseph Ratzinger, ed. M.J. Miller. San Francisco: Ignatius Press, 2011.

"Theology of the Liturgy: Lecture Delivered During the Journess Liturgiques de Fontgombault", dalam The Essential Pope Benedict XVI: His Central Writings and Speeches, eds. J.F Thonton dan S.B Varenne (Harper Collins e-book).

Christian Brotherhood (London and Melbourne: Sheed \& Ward/ Stagbooks, 1966) 